\title{
Geographical Approaches to the Study of the Urban Environment
}

\author{
Kubishkina E. N. ${ }^{1} \&$ Rafikova F. Z. ${ }^{1}$ \\ ${ }^{1}$ Kazan Federal University, Institute of Management, Economics and Finance, Kazan, Russia \\ Correspondence: Kubishkina E. N., Kazan Federal University, Institute of Management, Economics and Finance, \\ Kazan, 420008, Russia.
}

Received: December 27, 2014 Accepted: February 19, 2015 Online Published: April 30, 2015

doi:10.5539/ass.v11n11p131

URL: http://dx.doi.org/10.5539/ass.v11n11p131

\begin{abstract}
This paper discusses geographical approaches c environmental studies taking into account natural and anthropogenic factors. Focuses on the methodology for assessing the ecological status of urban areas. We consider a system of evaluation criteria in geo-environmental situation. To assess the geo-ecological situations previously summarized the main factors of its creation in the form of diagnostic features. Among the main factors affecting the natural geo-ecological situation (ecological framework) and anthropogenic. By the example of Kazan celebrated territorial and geo-ecological zones of the most important features."
\end{abstract}

Keywords: geographical area, diagnostic characteristics, correlation coefficients

\section{Introduction}

Currently, geo-environmental problems by severity and urgency of their decisions are in line with the social and economic development issues, so their study cannot be carried out a holistic study of the whole complex social, ecological and economic factors shaping the environment of the society in a certain area (Gaisin \& Biktimirov, 2014; Mazzotti \& Morgenstern, 1997; Hearn, Collie, Lyle, Choi, \& Foth, 2014; Wu, Xiang, \& Zhao, 2014).

When diagnosing various aspects of geo-ecological conditions in the city demographic processes are particularly relevant, since the concentration of the population increases the strength and character of human impact on the environment.

Therefore, the study of environmental problems of urban areas at the present stage of development and distribution of urban life is one of the urgent tasks (Liu, 2011; Wu, 2014; Kattel, Elkadi, \& Meikle, 2013).

The notion of sustainability geoekosistemy and its characteristics, such as a measure of complexity, diversity, ecological capacity thresholds geoekosistemy find use in a variety of tasks environmental focus , in particular, when assessing the ecological state of the city or geoekosistemy and isolation zones of ecological risk

Several authors have suggested various methods and approaches to urban environmental assessment.

Strategic environmental assessment (SEA) has become an increasingly important decision-support tool for providing information on the environmental implications of a policy, plan, or program. A multi-criteria indicator matrix quantifies the socio-environmental impact on both urban greenery and residents. The analysis is done in relation to the goals of environmental sustainability to be pursued and the main characteristics of cities (e.g. population) (Li, Xie, \& Hao, 2014; Schetke \& Haase, 2008; Russo \& Comi, 2012; 1995).

\section{Methodology and the Main Part}

As a rule the interpretation of ecological-geographical data comes to the problem of classification of a variety of indicators (used to describe this information) or the elements of this complex system. Most commonly the classifications are used as assumptions stating that one and the same set of characteristics describes all the objects of the system, while the objects differ by the set of meanings of characteristics. This principle is the basis of all formal procedures of classification and division into regions. Informal classifications of complex geographical objects in their turn are created on the basis of only a certain part of the characteristics of the object. All possible combinations of characteristics can not and should not be used; taking into account the amount of work it involves and, which is vitally important, the informative value of characteristics can be overlapped creating so called "white noise" distorting the final results of the work. Moreover, as a rule, the set of characteristics is good only for general description while content division requires diagnostic characteristics. 
In this respect there arise procedures typical of every object of the set of characteristics, reflecting the peculiar fragment of the content. It is necessary to develop single interdependent set of characteristics allowing finding major differences with other objects of the system. It is called regional syndrome of characteristics.

This syndrome allows determining regional syndrome of certain territorial parts. In general the work is carried out with operationally-territorial units (OTU). It can be systematically or mathematically outlined squares of common net, applied onto the territory; separate districts, states and other territorial units; in some cases estuaries of rivers; other geographical territorial units or separate objects (enterprises, households, rural settlements, cities etc.). The major method of determining the regional syndrome lies in the calculation of taxonomical distance of a given characteristic within certain OTU using the meaning of the corresponding characteristic of the elements of the system.

Numerous procedures of classification and regional division in geography are accompanied by point assessment of the meanings of characteristics with subsequent totaling up the points. In this case the procedure of totaling up should be accompanied by arranging or "evaluation" of points. "Evaluation" procedure can be of different quality There exist a number of comparisons based on correlation factor, introduced by V. V. Shkurkov in 1967 and slightly modified since then.

\section{Result}

Here is presented a system of evaluation criteria of geoecological situation in the city (Figure 1).

For the evaluation of geoecological situation there have been preliminary generalized main factors of its creation in the form of looking for diagnostic (critical) characteristics. Among the main factors influencing the geoecological situation are natural (ecological framework) and anthropogenic ones. The following indicators have been used as evaluation criteria:

- Integral natural - ecological potential of the territory

- Urban differences in provision of planting and the estimation of available natura public recreation sites, trees planting in the district (1) the area of green sites per one person (2) the share of Extremal Safty Natural Territory (ESNT) or, as called in some countries - National Park, in the total area of the district(3).Generalized characteristic of spatially distributed concentration of population has become the synthesis of indicators such as density of population (4), the coefficient of death-rate (6), criminal rate (7), unemployment rate (8).

Total concentration of industry is based on the following indicators: IIP (index of industrial pollution) (9), number of air pollution sources (10).

Generalized analysis of concentration of transport has been carried out by the author according to the following indicators: thickness of roads with hard surfacing (11), ISP (index of snow cover pollution)(12), the summary of the index of snow cover pollution (SiSCP5) based on 5 most polluted elements $\mathrm{Cu}$ (copper), $\mathrm{Zn}$ (zinc), $\mathrm{Mg}$ (mergansers), $\mathrm{Cr}$ (chrome), Ni (nickel) (13).

Concentration of infrastructure is reflected by the following indicators: being provided with trading floors (sites), being provided with available seats at public food sites, specific gravity of non-standard water samples according to sanitary hygienic indicators (17).

As the indicative evaluative criteria the following integral indicator has been chosen - "Population's sickness rate of socially-significant diseases" (16) which in the synthesized form reflects impact of the environment on the human being.

As a rule, the processing of geoecological data comes to the problem of classification of a multitude of indicators (characteristics). For each OTU it is necessary to develop an interdependent set of characteristics which would allow finding major differences with other OTUs. So, at the preliminary stage of research there has been done expert selection and grouping of main indicators taking into account their significance and informative value, which has resulted in the creation of the system made up of 17 diagnostic indicators connected with the administrative regions of Kazan.

The main methodical approach when carrying out typological classification of administrative regions of Kazan according to the level of intensity of geoecologjcal situation is the unification of districts in relation to the sum of "evaluated" points, keeping in mind that arithmetical operations with points are possible only if they have been "evaluated". The regulation of indicators with the aim of developing unified measurement was carried out by means of bringing the scale of indicators' meanings to the supporting 5 point scale (Table 1).

Table 1 shows the level of influence of each diagnostic factor through the amount of corresponding point on the level of intensity of geo-ecological state. 
According to methodic, the procedure of indicators' "evaluation" was carried out by means of correlative method, which resulted in outlining most significant and common indicator "Sickness rate of socially significant diseases (P total) each of the indicators $\mathrm{P}_{\mathrm{i}}$ ) was compared with. While determining the coefficient of correlation $\left(\mathrm{r}_{\mathrm{i}}\right)$ used only as a measure of coordination and interdependence, it was made known that the maximum meaning (according to a module) is the one of closeness of relation between (P total) and $\mathrm{P}_{14}$ "SISCp5" (rl4=0,80) (Table 2).

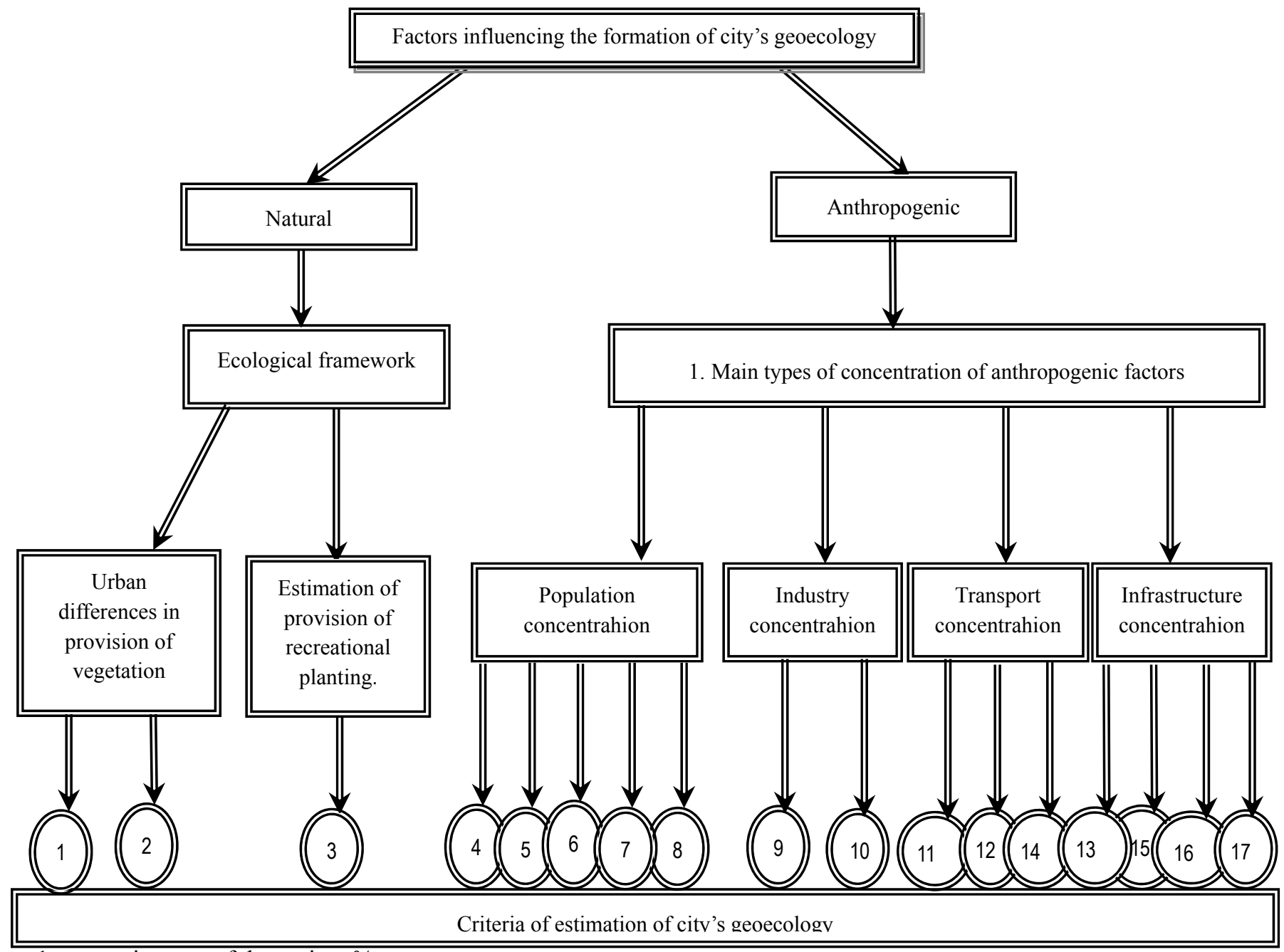

1. vegetation rate of the region, $\%$

2. area of controlled planting calculated per 1 person, sq. meters/person

3. proportion of OOPT in total area of the region, $\%$

4. density of population, people/sq. $\mathrm{km}$.

5. sickness rate of socially significant diseases

6. coefficient of total death-rate

7. criminal record

8. level of unemployment, $\%$

9. Iff (index of industrial pollution)

10. amount of sources of air pollution

11. thickness of roads with hard surfacing

12. IAP (index of air pollution)

13. SiSCP5

14. provision with aver table seats, seats $/ 1000$ people

15 provision of population of trading floors, sg.m/1000

16. special gravity of non-standard water samples according to sanitary

17. special gravity of non-standard water samples according to micro-biological characteristic

Figure 1. Factors influencing the formation of city's geoecology 
Table 1. The scale of diagnostic characteristic

\begin{tabular}{|c|c|c|c|c|c|}
\hline Characteristic & point & Characteristic & point & Characteristic & point \\
\hline $\begin{array}{l}\text { 1. Planting-rate in } \\
\text { the region, } \%\end{array}$ & & $\begin{array}{l}\text { 2. Area of vegetation per } 1 \text { person, } \\
\text { sg.m. }\end{array}$ & & $\begin{array}{l}\text { 3. Proportion of } \\
\text { (ESNT) in total area } \\
\text { of the region, } \%\end{array}$ & \\
\hline $1,71-8,12$ & 1 & $13.8-75,26$ & 1 & $<0,0008$ & 1 \\
\hline $8,13-14,54$ & 2 & $75,27-136,73$ & 2 & $0,008-9,97$ & 2 \\
\hline $14,55-20.96$ & 3 & $136,74-198,2$ & 3 & $9,98-19,94$ & 3 \\
\hline $20,97-27,38$ & 4 & $198,3-259,76$ & 4 & $19,95-29,91$ & 4 \\
\hline $27,39-33,8$ & 5 & $259,77-321,1$ & 5 & $29,92-39,87$ & 5 \\
\hline $\begin{array}{l}\text { 4. Density of } \\
\text { population number } \\
\text { of people/sg.km }\end{array}$ & & $\begin{array}{l}\text { 5. Sickness-rate of population socially } \\
\text { significant diseases }\end{array}$ & & $\begin{array}{l}\text { 6. Coefficient of } \\
\text { death-rate }\end{array}$ & \\
\hline $980-2767,4$ & 1 & $577-591,08$ & 1 & $12.8-13,42$ & 1 \\
\hline $2767,5-4554,9$ & 2 & $591.09-605.17$ & 2 & $13,43-14,05$ & 2 \\
\hline $4555-6342,4$ & 3 & $604,18-619,26$ & 3 & $14,06-14.68$ & 3 \\
\hline $6342,5-8129,9$ & 4 & $619,27-633,35$ & 4 & $14.69-15,31$ & 4 \\
\hline $8130-9917$ & 5 & $633,36-647,4$ & 5 & $15,32-15,9$ & 5 \\
\hline $\begin{array}{l}\text { 7. Criminal record } \\
\text { level }\end{array}$ & & 8. Level of unemployment, $\%$ & & $\begin{array}{l}\text { 9. IIP (index of } \\
\text { industrial pollution) }\end{array}$ & \\
\hline $1414-1715,2$ & 1 & $0,43-0,62$ & 1 & $10-14$ & 1 \\
\hline $1715,3-2016,5$ & 2 & $0.63-0,82$ & 2 & $15-19$ & 2 \\
\hline $2016,6-2317,8$ & 3 & $0.83-1,02$ & 3 & $20-24$ & 3 \\
\hline $2317,9-2619,1$ & 4 & $1.03-1,22$ & 4 & $25-29$ & 4 \\
\hline $2619,2-2920$ & 5 & $1,23-1,42$ & 5 & 30 & 5 \\
\hline $\begin{array}{l}\text { 10. Amount of } \\
\text { sources of air } \\
\text { pollution, sg.m. }\end{array}$ & & $\begin{array}{l}\text { 11. Thickness of roads with hard sur } \\
\text { facing, } \mathrm{km} / \mathrm{sg} . \mathrm{km}\end{array}$ & & $\begin{array}{l}\text { 12. IAP (index of air } \\
\text { pollution) }\end{array}$ & \\
\hline $0,3-1,08$ & 1 & $0,92-1,89$ & $\mathbb{1 1}$ & $0,416-0,499$ & 1 \\
\hline $1,09-1,87$ & 2 & $1,90-2,87$ & 2 & $0,500-0,583$ & 2 \\
\hline $1,88-2,66$ & 3 & $2,88-3,85$ & 3 & $0,584-0,667$ & 3 \\
\hline $2,67-3,45$ & 4 & $3,86-4,83$ & 4 & $0,668-0,751$ & 4 \\
\hline $3,46-4,2$ & 5 & $4,84-5,81$ & 5 & $0,752-0,835$ & 5 \\
\hline 13. SISCp5 & & $\begin{array}{l}\text { 14. Provision with aver table seats, } \\
\text { seats } / 1000 \text { people }\end{array}$ & & $\begin{array}{l}\text { 15. Provision of } \\
\text { population of trading } \\
\text { floors, sg.m/1000 }\end{array}$ & \\
\hline $9,98-10,8$ & 1 & $3,65-49,60$ & 1 & $108-388,4$ & 1 \\
\hline $10,9-11,8$ & 2 & $49,61-95,56$ & 2 & $388,5-668,9$ & 2 \\
\hline $11,9-12,8$ & 3 & $95,57-141,52$ & 3 & $669-949,4$ & 3 \\
\hline $12.9-13,7$ & 4 & $141,53-187,48$ & 4 & $949,5-1229,9$ & 4 \\
\hline $13,8-14,7$ & 5 & $187,49-233,4$ & 5 & $1230-1510$ & 5 \\
\hline $\begin{array}{l}\text { 16. Special gravity } \\
\text { of non-standard } \\
\text { water samples } \\
\text { according to } \\
\text { sanitary }\end{array}$ & & $\begin{array}{l}\text { 17. Special gravity of non-standard } \\
\text { water samples according to } \\
\text { micro-biological characteristic }\end{array}$ & & & \\
\hline $14,5-17,3$ & 1 & $3,8-4,6$ & 1 & & \\
\hline $17,4-20,2$ & 2 & $4,7-5,4$ & 2 & & \\
\hline $20.3-23,0$ & 3 & $5,5-6,3$ & 3 & & \\
\hline $23,1-25,9$ & 4 & $6.4-7.1$ & 4 & & \\
\hline $26,0-28,8$ & 5 & $7.2-8,3$ & 5 & & \\
\hline
\end{tabular}


Table 2. Correlation and "evaluation" coefficients

\begin{tabular}{llllllll}
\hline \multicolumn{3}{c}{ Correlation coefficients } & \multicolumn{5}{c}{ Correlation "evaluation" } \\
\hline $\mathrm{r} 1=$ & 0,46 & $\mathrm{r} 10=$ & 0.04 & $\mathrm{j} 1=$ & 0,57 & $\mathrm{j} 10=$ & 0,05 \\
$\mathrm{r} 2=$ & 0,45 & $\mathrm{r} 11=$ & 0,11 & $\mathrm{j} 2=$ & 0,56 & $\mathrm{j} 11=$ & 0,13 \\
$\mathrm{r} 3=$ & 0,76 & $\mathrm{r} 12=$ & 0,09 & $\mathrm{j} 3=$ & 0,95 & $\mathrm{j} 12=$ & 0,11 \\
$\mathrm{r} 4=$ & 0,37 & $\mathrm{r} 13=$ & 0,24 & $\mathrm{j} 4=$ & 0,46 & $\mathrm{j} 13=$ & 0,30 \\
$\mathrm{r} 6=$ & 0,11 & $\mathrm{r} 14=$ & $\mathbf{0 , 8 0}$ & $\mathrm{j} 6=$ & 0,13 & $\mathbf{j} 14=$ & $\mathbf{1 , 0 0}$ \\
$\mathrm{r} 7=$ & 0,05 & $\mathrm{r} 15=$ & 0,64 & $\mathrm{j} 7=$ & 0,06 & $\mathrm{j} 15=$ & 0,80 \\
$\mathrm{r} 8=$ & 0,14 & $\mathrm{r} 16=$ & 0,21 & $\mathrm{j} 8=$ & 0,17 & $\mathrm{j} 16=$ & 0,26 \\
$\mathrm{r} 9=$ & 0,15 & $\mathrm{r} 17=$ & 0,11 & $\mathrm{j} 9=$ & 0,18 & $\mathrm{j} 17=$ & 0,13 \\
\hline
\end{tabular}

While determining the coefficients of "evaluation" $\left(\mathrm{J}_{\mathrm{i}}\right)$ each of the received $\left(\mathrm{r}_{1}\right)$, is related to $\left(\mathrm{r}_{\max }\right): \mathrm{J}_{\mathrm{i}}=\mathrm{r}_{\mathrm{i}} / \mathrm{r}_{\max }, \mathrm{i}=$ $1-17, \mathrm{~J}_{\mathrm{i}}>0$

The meaning $(J)$ was multiplied by a corresponding to each of them meaning of the point, as a result of which there has been compiled a matrix of 'evaluated" points leading to the totaling up of points for each OTU.

The results were used to outline the gradation of the "evaluated" points' sums according to the formula: $K_{i}=C(Z)$ $\max ^{-} \mathrm{C}(\mathrm{Z})_{\min } / \mathrm{n}$

The subsequent calculations and analysis allowed to single out three groups of administrative regions with different criticality of geoecological state: C (z) 6, 95-10,85(1) - fairly successful; 10,86-14,75 (2)-moderately tense; 14,76-18,66(3)-tense.

On the base of typological classification there has been carried out geoecological region Applying the methodology of spatial analysis of outlining geoecological regions of Kazan division of Kazan by means of cartographic generalization of depicted territory which leads to diminishing the borders when substituting subdivided units (administrative districts) by larger ones (geoecological regions).

As a result of cartographic generalization of subdivided units into larger ones, adequate to complex characteristic of the region, there have been formed three geoecological regions: of moderate ecological comfort (I), moderate ecological well-being (II), and moderate ecological trouble (in). Within the Il-nd geoecological region there have been outlined 3 types: $a$ - industrially-living; $b$ - administrative living (the City).

I a - geoecological region of moderately ecological comfort (occupying about $1 / 30$ of the area and $30 \%$ population of the city) is represented by industrially-living administrative districts (totaling 2) Aviastroitelniy and Privoljskiy, which possess vast industrial territories of the city. Within this sector the ecological tension is leveled by favorable geographical position (located in the northern and southern suburbs of the city) and neighboring with Visokogorskiy and Laishev districts. Moreover this group is positively influenced by the Volga basin.

II a,b,c - geoecological region is the one of moderate well-being and is characterized by moderately-tense geoecological situation. It is represented by 4 administrative units -Vakhitov, Novo-Savinov, Soviet and Moscow districts.

From the geographical point of view geoecological region (II a,b,c) is located in the central part of the city and experiences the impact of other 2 regions. It's total area occupies $1 / 3$ of the area and $61 \%$ population of the city. So, this geoecological region is most densely populated. Two regions are located on the left bank of the Volga and Kazanka rivers - Vakhitov and Soviet, and two in Zarechye and on the right bank. Moscow and Soviet districts belong to the type II a, Novo-Savinov district belongs to type II b and Vakhitov and the City belong to type II c. The City is the administrative and historical center of Kazan possessing a few industrial sites. Here can be found the majority of educational institutions as well as administrative, trading, business, cultural and entertainment organizations and cultural and architectural attractions. As a result of out-of-date houses elimination program the district has lost most of living buildings. As for population this district is the least populated one in the city. But it is very busy during the day because of the inflow of population and transport towards the centre of the city.

The region of III a geo-ecologically troubled type is characterized by tense geoecological situation. This region includes only one district called Kirov. It is located in the west of the city in Zarechye area. It is an industrially-living district, one of the oldest in Kazan. It borders on Zelenodolsk and occupies $1 / 4$ of the territory and $9 \%$ population of the city (maple-chart). 


\section{Conclusion}

Kazan treated as an object of nature and man-made impacts for each major city is a specific interweaving of social, economic, ethnic, national, environmental and other issues, resulting in the formation of the specificity of the urban environment and features of the population living in them.

First in the geo-environmental character tested method to identify significant relationships between the characteristics of the environmental and socio -economic situation in relation to major cities. The analysis and evaluation of the environmental and socio -economic situation in terms of the possibilities of their use in the environmental mapping using GIS technologies.

Concentration (population, industry, transport and infrastructure) in a relatively small area of intense human impact specificity geographical location and the device surface of the city, have defined their characteristic Kazan ecological situation, which is generally more difficult than in many major cities.

\section{References}

Gaisin, I. T., \& Biktimirov, N. M. (2014). Migration Processes in the Republic Tatarstan in the Second Half of the 20th and in the Early of 21st Centuries: Ethnic and Social Aspects. Middle-East Journal of Scientific Research, 20(12), 1761-1766. http://dx.doi.org/10.5829/idosi.mejsr.2014.20.12.21088

Hearn, G., Collie, N., Lyle, P., Choi, J. H.-J., \& Foth, M. (2014). Using communicative ecology theory to scope the emerging role of social media in the evolution of urban food systems. Futures, 62, 202-212. http://dx.doi.org/10.1016/j.futures.2014.04.010

Kattel, G. R., Elkadi, H., \& Meikle, H. (2013). Developing a complementary framework for urban ecology. Urban Forestry \& Urban Greening, 12, 498-508. http://dx.doi.org/10.1016/j.ufug.2013.07.005

Li, W., Xie, Y. B., \& Hao, F. H. (2014). Applying an improved rapid impact assessment matrix method to strategic environmental assessment of urban planning in China. Environmental Impact Assessment Review, 46, 13-24. http://dx.doi.org/10.1016/j.eiar.2014.01.001

Liu, Y. (2011). Assessment of City Environmental Quality in Western China Based on Matter Element Extension: A Case Study of Chongqing. Energy Procedia, 5, 619-623. http://dx.doi.org/10.1016/j.egypro.2011.03.108

Mazzotti, F. J., \& Morgenstern, C. S. (1997). A scientific framework for managing urban natural areas. Landscape and Urban Planning, 38, 171-181. http://dx.doi.org/10.1016/S0169-2046(97)00032-7

Russo, F., \& Comi, A. (2012). City Characteristics and Urban Goods Movements: A Way to Environmental Transportation System in a Sustainable City. Procedia - Social and Behavioral Sciences, 39, 61-73. http://dx.doi.org/10.1016/j.sbspro.2012.03.091

Schetke, S., \& Haase, D. (2008). Multi-criteria assessment of socio-environmental aspects in shrinking cities. Experiences from eastern Germany. Environmental Impact Assessment Review, 28, 483-503. http://dx.doi.org/10.1016/j.eiar.2007.09.004

The effect of urban pollution on lead levels in air of the city of Valencia (Spain). (1995). Science of The Total Environment, 162, 111- 117.

$\mathrm{Wu}$, J. G. (2014). Urban ecology and sustainability: The state-of-the-science and future directions. Landscape and Urban Planning, 125, 209-221. http://dx.doi.org/10.1016/j.landurbplan.2014.01.018

Wu, J. G., Xiang, W.-N., \& Zhao, J. Z. (2014). Urban ecology in China: Historical developments and future directions. Landscape and Urban Planning, 125, 222-233. http://dx.doi.org/10.1016/j.landurbplan.2014. 01.018

\section{Copyrights}

Copyright for this article is retained by the author(s), with first publication rights granted to the journal.

This is an open-access article distributed under the terms and conditions of the Creative Commons Attribution license (http://creativecommons.org/licenses/by/3.0/). 